\title{
Rising against all odds: An analysis of the leadership experiences of three female clergy in the Methodist Church in Zimbabwe
}

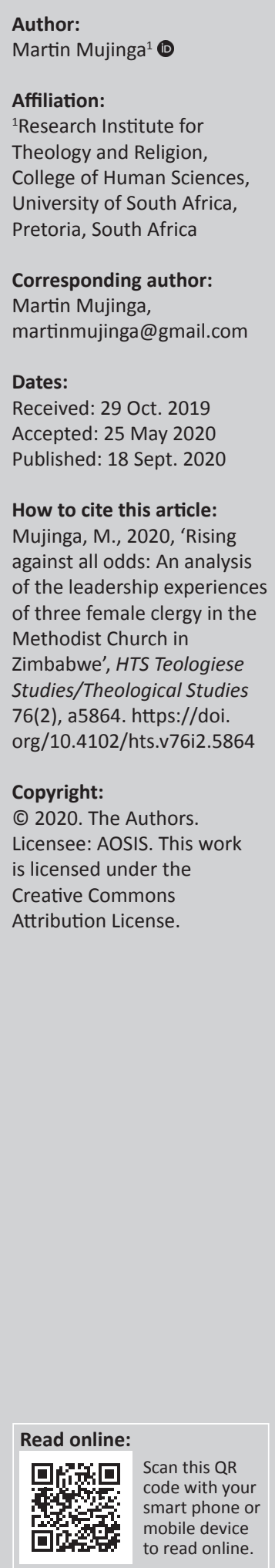

The Methodist Church in Zimbabwe (MCZ) was established in 1891. In 1977, it was granted autonomy by the British Methodist Church. From 1891, top church leadership has been dominated by male clergy. This article explores three instances of a challenge to this trend. The first occurred in 1994 when there was a leadership crisis in one of the districts, and for the first time, a woman was appointed district chairperson. The second followed the election in August 2004 of a male presiding bishop. However, allegations of moral impropriety were made against him. He approached the secular courts, and it led to his withdrawal from the position. The church appointed a woman to the position of acting presiding bishop. When the time came for the substantive post to be filled in August 2005, she was not confirmed in the position; a man was elected instead. The third relates to the controversial appointment in 2017 of a woman to one of the five vacant positions of district bishops. The aim of the research was to analyse the way in which these three women rose to positions of leadership in a male-dominated church. A qualitative research methodology was followed, with data being collected through openended interviews. The study highlighted that to be a female clergy leader in the MCZ entails rising against all odds. The study concluded by encouraging the MCZ to support women on their path to leadership rather than overlooking or, worse still, undermining them.

Contribution: In spite of the challenges female clergy face in their quest for leadership roles, this feminist ecclesiological study shows stories of rising against all odds, describing the momentum-gaining progress of the ecclesiastical effort in the MCZ to accommodate female leaders, despite slow-moving processes.

Keywords: Rising against all odds; Leadership experiences; Three female clergy; Methodist Church in Zimbabwe; Bishop.

\section{Introduction ${ }^{1}$}

From the time of the establishment of the Methodist Church in Zimbabwe (MCZ) in 1891 up until 1994, leadership in the church was exclusively male. The church was granted autonomy ${ }^{2}$ in 1977 (Mujinga 2017), and the ecclesiastical history of the MCZ shows that women have not been encouraged to assume leadership positions (Mujinga 2019). The first woman to hold the position of district chairperson (now bishop) was Margaret Mawire, who was appointed after the male leader of the district was subjected to a disciplinary process during the course of the year (Mujinga 2017:166). The second woman to hold office, Margaret James, was appointed acting presiding bishop when the male incumbent was withdrawn a week before he was due to assume office (Ruwona 2009:68). She remained in office for only 8 months. In spite of the fact that she stabilised the church, which was on the verge of a schism on both ecclesial and legal grounds, when the time came for the substantive post to be filled she was not elected, and a man was elected instead. The third woman to hold high office in the church was Chishamiso Nyabonda, who was appointed district bishop in 2017 (MCZ 2017:33). This appointment was a controversial one, as Nyabonda herself explains. The experiences of these three women merit scholarly research to

1.This research was first presented at the conference of the Theological Society of South Africa in collaboration with the Church Leadership Cluster held from 17 to 19 June 2019 in Pretoria, South Africa. The purpose of the conference was to examine the theological role of church leaders across the ecclesiastical spectrum. The difficulties experienced by women in achieving top leadership positions were found to be a common theme across continents, religions, disciplines and philosophies.

2.The term 'autonomy' refers to the ecclesiastical independence afforded to a local church. Since Methodism in Zimbabwe was under the British Conference, in 1977, it was elevated from district to conference status. This autonomy meant that it would from then on elect its own leaders and also raise and manage its own funds (Mujinga 2017:147). 
investigate why women are repeatedly relegated to the periphery in the context of church leadership.

The reasons for the continued exclusion of women from positions of leadership have been intensively researched by both male and female scholars, who are generally in agreement that the literature on women in leadership has focussed on the contextual factors that continue to support the progression of men to top positions at the expense of women (Budworth \& Mann 2010:2). Although there is a vast amount of academic research on leadership available online; a Web of Science search indicated that of more than 165000 articles on the subject, a mere 5\% discuss women in leadership (Gippson et al. 2017:33). Scholars such as Singh and Durga Prasad (2007), Elmuti, Jia and Davis (2009) and Budworth and Mann (2010) have drawn attention to the prevalence of factors such as the glass ceiling, ${ }^{3}$ organisational policies and practices, patriarchal cultures, stereotyping, gender bias and discrimination against women and male hegemony, and their contribution to the exclusion of women from positions of leadership. In spite of the extensive research conducted by these scholars in the corporate world, the recognition of women in leadership in theology remains an underexplored area. Oduyoye, cited in Phiri, Govinden and Nadar (2002:ix), lamented the fact that most historical books and accounts have excluded the role played by women of faith. The spirituality of these women nourished people's faith and lives, but the chroniclers have been silent regarding their stories or relegated them to the footnotes and appendices of men's stories. The concern expressed by Oduyoye is one of the reasons for recounting and analysing how the three women rose against the odds to be leaders in the MCZ. In my view, the narratives of the three women whose stories are told in this article, who defied the odds, deserve to be heard both because of their personal achievement in the context of female ministry in the MCZ and because there is no scholarly literature on women in leadership ${ }^{4}$ in the MCZ. This research therefore aims to take the hidden stories of women from the periphery to the centre of Methodist ecclesia.

This work is a continuation of my research presented on the International Day for Women organised by the University of Zimbabwe and Embassy of Iran on 01 March 2019, when I stated that of a total of 290 ministers in the MCZ, only 54

3.The glass ceiling is a reference to an invisible barrier that prevents a given demoraphy from rising beyond a certain level in a hierarchy. The metaphor was first coin first coined by feming advancement in a profession, especially one limiting women and members of advancement in a professior
minorities (Reiners 2019).

4.The role of women in the MCZ has not hitherto received scholarly attention. Thorpe (1951) wrote about the general history of Methodism in Zimbabwe from 1891 to 1951, whilst Zvobgo (1991) concentrated on the Methodist missions in Zimbabwe from 1891 to 1945. Banana (1991) traced the historical development of Methodism up to 1991 because the MCZ was preparing for its centenary celebration, and so an account of the struggles and achievements of the church was deemed both necessary and appropriate for the occasion. Madhiba (2010) focussed his research on the Methodist Church's role in politics, while Gondongwe (2011) analysed the responses of African ministers to the ill-treatment meted out at the hands of the responses of African ministers to the ill-treatment meted out at the hands of the missionaries and how resistance to colonial domination shaped the development of indigenous clergy in the MCZ. Mujinga (2017) investigated the development of Methodism across its trajectory from 17th-century England to Zimbabwe in 2017; this study spanned five centuries, but women were considered only in the contex of general women's fellowship, and not in the context of the clergy. It is the absence of a focus on women in leadership roles in the MCZ that provided the impetus fo this research. were women, and as of 2018, only one woman held the position of district bishop, and three synod secretaries ${ }^{5}$ and 13 superintendents were women. The research focussed on analysing how the MCZ achieves theological and cultural balance in its effort to appoint ecclesiastical leaders on merit. The conclusion reached was that the patriarchally inspired appointments of leaders in the MCZ over the years have been influenced by African culture, which states that 'the man is always the head' (Mujinga 2019).

For the sake of continuity, the conceptual framework, research method and design will be discussed first. This will be followed by the working definition of the phrase, 'against all odds'. The article will further analyse the obstacles encountered by women aspiring to become leaders in a maledominated context, before proceeding to a discussion of the shortcomings of the MCZ. The narratives of the three selected female clergy will be explored thereafter. The article will conclude with a call to the MCZ to make a concerted effort to welcome and encourage women who wish to take on leadership roles.

\section{Conceptual framework}

Knödel (1997:240) stated, 'Feminist ecclesiology points to a more complex understanding of theological reflection and the mission of the church'. This principle was adopted for the purpose of the study undertaken, based on the notion that when the story of the church is studied from a feminist perspective, the contextual consideration of that particular church order is called for. The proportional imbalances in the MCZ ecclesiastical leadership require the female ecclesiological structure to respond to the plight of women. For example, Watson (2002:8) expressed the view that women cannot be content with simply being assured that they are part of the church as a spiritual body, when their presence and participation are not recognised.

This particular conceptual framework was selected for the research undertaken because, throughout most of church history, women have not participated in the leadership life of the church, and this framework makes provision for women's voices to be heard in the Methodist ecclesia. It is my view that feminist ecclesiology grew out of the need for the church to redefine itself in the context of a maledominated society. This redefinition and rereading of the church's ecclesiastical theology considered feminist ecclesiology so as to constitute the reclaiming of an area of theology and the life of the church that in the past was largely a male domain (Watson 2002:13).

In the context of this research, female ecclesiology is not understood as thinking and speaking theologically about the church as an institution; it goes beyond this to consider a variety of models by which the church describes itself in theological terms (Watson 2002:9). This framework was

5.Synod refers to a meeting of all ministers in the district and lay persons under the regulations of the conference (MCZ 2011:28). The MCZ has eight districts; the synod
secretary is the administrator of the district, while the district bishop is the chief shepherd. 
selected for the study because of its potential for providing answers to the question of what made it possible for the three women whose stories were investigated to succeed in spite of the odds. In this research, female ecclesiology also grapples with a number of factors in the MCZ, such as how one qualifies to be a leader, support for women leaders, the pastoral training of the female incumbent, the inconsistencies in the voting system and processes in the MCZ that work together to make women in leadership feel inferior. A consideration of these factors will reveal what enormous odds these women overcame.

\section{Research methodology and design}

According to Patton and Cochran (2002:3), 'qualitative research aims to understand the experiences and attitudes of people'. In this research, a qualitative research methodology was followed, entailing the use of both primary and secondary sources. Primary sources took the form of interviews, whilst secondary sources comprised published literature. Open-ended interviews were conducted with the three female leaders and the former Presiding Bishop, Revd Cephas Mukandi. Open-ended interviews allow the interviewer to build rapport with respondents, encouraging them to open up and express themselves in the framework they choose. Finch (1984:72) held that in research, people prefer less structured research strategies which avoid creating a hierarchal relationship between the interviewer and interviewee'. For Finch (1984:72), 'a hierarchical relationship is inappropriate for females because it objectifies them'. All the interviews were recorded and transcribed subject to the research ethical non-coercive disclaimer that interviewees are free to leave the interview session whenever they wish to without being penalised, that participation in the interview is voluntary and that the interview will be used exclusively for academic purposes (Oddi \& Cassidy 1990:24).

Literature on women in leadership and the MCZ ecclesiological structure was the main topic for this research. A visit was made to the $\mathrm{MCZ}$ archives in Harare in November 2019. The MCZ archives contain all minute books, handbooks and accounting books relating to trust, circuit or society affairs that are no longer needed for current reference in the conduct of business (MCZ 2011:35). These sources have been kept since 1891. The archives were accessed with the permission of the general secretary, who is the custodian of the intellectual property of the MCZ (2011:208). If we are to appreciate the barriers that were overcome by the women on whom this study focusses, a working definition of the phrase 'against all odds' is necessary, and this will be formulated in the defining the phrase, 'against all odds' section.

\section{Defining the phrase, 'against all odds'}

The Online Merriam Webster Dictionary (2005) defined the phrase 'against all odds' as 'despite success being very unlikely'. This definition suggests that if something happens against all odds, it succeeds even though it seemed impossible. Fiedler cited in Phiri et al. (2002:189) stated that the phrase against all odds depicts women's initiatives to challenge the missionary dictates upon them not to be involved in the church's leadership roles. The phrase should therefore be understood in light of the way in which missionary policy gendered the role of the pastor. In the MCZ, patriarchy and male dominance are not a new phenomenon: the missionaries who brought Methodism from Britain were all male, and they were subsequently joined by 10 male South African teacher-evangelists (Banana 1991; Gondongwe 2011; Madhiba 2010; Mujinga 2017; Thorpe 1951; Zvobgo 1991). For Mujinga (2019), this male face of Methodism translated into the notion that 'Methodist is male and male is Methodism'. This, then, clearly justifies the use of the phrase 'against all odds' in this research to reflect the extraordinary achievement of the women whose stories are told here.

\section{The struggle waged by women to become leaders in a male-dominated society}

Paustian-Underdahl, Slattery Walker and Woehr (2014 :1129) drew our attention to the fact that although the proportion of women in the corporate workplace has increased remarkably over the past few decades, women nevertheless remain vastly underrepresented at the highest organisational levels. Paustian-Underdahl et al. (2014:1129) added that although the number of women in managerial positions has been increasing, the gender composition of top management became skewed, and it is evident that there are barriers and obstacles in the workplace that limit the progression of women in leadership roles. Singh and Durga Prasad (2007:50) further stresses that over the years, femininity has been stereotypically associated with dependency and submissiveness, and therefore women continue to be regarded as lacking in leadership qualities.

In the context of Methodist ecclesiology in Africa, the exclusion of women from positions of leadership was highlighted by Kumalo (2016) in his research into the experiences of female clergy in the Methodist Church of Southern Africa (MCSA). Kumalo (2016:174) concluded that whilst women have been ordained to the ministry of Word and Sacrament since 1976, they remain a numerical minority, and continue to be marginalised within the context of leadership roles. For Kumalo (2016:175), ordained women remain both unrecognised and underutilised in the MCSA. Within the MCZ context, Mujinga (2019) explained that superintendence $^{6}$ is a prestigious position attained through competency, whilst being a circuit minister ${ }^{7}$ is viewed as synonymous with non-efficiency or non-competence. The word 'competency' here stands as a code for maleness, with junior male ministers being appointed as superintendents, whilst some very senior and educated female ministers remain as circuit ministers (MCZ 2018:20-31).

6.A Superintendent is the minister whose name appears at the top of the list of ministers appointed to a circuit (MCZ 2011:29).

7.A circuit minister in the Methodist Church is a minister who is appointed to a circuit to discharge the specified responsibilities there. The circuit minister is any minister who is either under the care of the Bishop or who comes after the superintendent (MCZ 2011:31). 
This observation is supported by Elmuti et al. (2009:170), who made the observation that, 'some firms have large pools of qualified women and simply do not consider them for positions because there is lack of female mentorship'.

The study reported in the present article indicated that although the MCZ is one of the mainline churches and therefore in an excellent position to promote female ministry, the church nevertheless lacks a policy for the promotion of women to leadership positions. Instead of receiving support and encouragement, women elected to positions of leadership have their integrity placed under scrutiny and are often dehumanised ecclesiastically, socially and culturally, and their leadership skills subjected to criticism that their male counterparts never experience (Mujinga 2019). It is against this background that the ecclesiastical experiences of Revd Margaret James, Revd Margaret Mawire and Bishop Chishamiso Nyabonda will be explored to understand how they ascended the male-dominated MCZ hierarchical leadership structure. My intention in conducting the research reported on here was therefore to investigate the female leadership gap in the MCZ, as this had previously not received scholarly attention.

\section{Female ministry in the Methodist Church in Zimbabwe}

Methodist Church in Zimbabwe accepted the first female clergy in 1977 (Banana 1991; Gondongwe 2011; Mujinga 2017; Zvobgo 1991). The first MCZ female candidates were Sheila Eades and Margaret James. Eades discontinued her ministerial studies barely a year after being accepted and returned to Britain (M. James pers. comm., 28 November 2018). Following Zimbabwe's political independence in 1980, the MCZ accepted the first black female itinerant ministers in 1982; they were Margaret Mawire and Maybe Mugabe. The MCZ continued to accept female ministers, at times after an interval of three years. The details and names of these female ministers can be read in Mujinga (2019). The intake increased in 2004 when four female ministers were accepted. In 2005, six, amongst whom was Chishamiso Nyabonda, were accepted - this represented the largest number. Of the six, two were sent to United Theological College, whilst the remaining four, amongst whom was Nyabonda, were trained through distance learning with Theological Education by Extension.

In spite of the annual growth in the number of women ministers in the MCZ, the opportunities extended to women and men are unequal. The MCZ (2011) policy book - the Deed of Church Order and Standing Orders (DOCOSO) (MCZ 2011) clearly stated that:

$[W]$ omen who offer themselves for ministry shall do so under the same conditions as men in relation to candidature, training, probation, reception into full connexion, ordination, seniority, stationing, terms of service and retirement. (pp. 174-175)

This statement expresses the church's official position on gender in the ecclesiastical life of the MCZ. However, in reality, women cannot look forward to the same prospects in the $\mathrm{MCZ}$ as men.

In 2017, the MCZ celebrated 40 years of women in ministry, yet by that date, only three women had occupied high leadership positions. Of a total of 128 circuits in 2018, 116 had male superintendents, and only 12 had female superintendents (MCZ 2018:20-31). Of the 27 members of the 2019 Standing Committee, ${ }^{8}$ only four were women. In terms of academic achievement, of the 56 female ministers, including James and Mawire as supernumeraries, in the same year, 34 held diplomas, eight had completed bachelor's degrees, five held master's degrees, one had registered for a PhD and nine were students in training (Mujinga 2019). The underrepresentation of women in leadership as evidenced here is clearly not related to education, as a number of women held excellent qualifications, yet did not occupy positions of leadership. One may be led to ask whether the underrepresentation of women in leadership positions in MCZ is attributable to their gender. This question leads us to the narratives of the three subjects of this study. For the purposes of this research, we will not focus to any significant degree on their biographies but rather on those life events that defined their unique experiences in the leadership of the MCZ.

\section{The call, training and ministry of Margaret Mansel James}

James trained as a nurse at Bulawayo Central Hospital in 1958. In 1962, she went to Britain to do midwifery training. After qualifying, she returned to Bulawayo and worked for two years at Mpilo Hospital. She received God's call to become a local preacher during her years at Mpilo. In 1966, she furthered her training as a sister tutor through the University of Cape Town (UCT), with a view to becoming a missionary nurse. Whilst studying at UCT, she enrolled at the University of South Africa for a Bachelor of Arts degree majoring in Psychology and Biblical Studies.

The Rhodesian Synod ${ }^{9}$ was held in Harare in January 1976, and James was accepted as a candidate for 1977 ministry. James said, 'The question for the church was where to send me for theological' (M. James pers. comm., 28 November 2018). The challenge came because the liberation struggle had had a serious impact on UCT, with both students and lecturers being involved in party politics, which caused deep rifts (M. James pers. comm., 28 November 2018). Gondongwe (2011) cited one incident of such friction. In 1977, the Principal,

8.The Standing Committee of the MCZ is the statutory committee that acts between the close of any meeting or conference and the opening of the succeeding meeting or conference. During this period, the Standing Committee is authorized to act on behalf of the conference, and then report to the conference (MCZ 2011:24).

9.From 1891 until 1977, the word 'Synod' referred to the district under British Conference led by the general superintendent (Banana 1991; Gondongwe 2011; Zvoo 1991). When the MCZ became a conference in 1977, with the first black Zvobgo 191). Whe the MCZ became a conference in 1977, with the first black president being Andrew Ndhlela, who had been appointed as the first black chairman and general superintendent in 1965, the term general superintenden was changed to president (Zvobgo 1991:121). When Revd Prof. Canaan Banana became the state president in 1980, the MCZ changed the title of president to bishop. The title changed again in 2004 to presiding bishop, with the term bishop replacing district chairperson (MCZ 2004). 
Revd Crispin Mazobere, presented a paper entitled, 'African religion and culture: The stone rejected by builders is the cornerstone', in which he argued (Gondongwe 2011):

The European missionaries' rejection of African traditional religion was tantamount to building a massive structure without a foundation. Christianity has become a tool for colonisation and the rejection of African culture is an act of taking away the identity of African people. If we believe that the appropriation of our land by the colonialists was wrong, then we must believe that the demonization of our culture by some missionaries is wrong too. We are not like Europeans who are so individualistic and think about themselves. (p. 208)

The expression of such views by the principal made UCT a difficult environment for a white Methodist minister to begin her training. The Methodist Church agreed to station James in Trinity Circuit as a pre-collegiate. In 1978, precollegiates were supposed to be sent for theological training. The MCZ agreed to send the white male students to train in Britain, whilst black students were sent to UCT (M. James pers. comm., 28 November 2018). As she was the only white female amongst this cohort, the church took her BA degree into consideration and encouraged her to register for a Bachelor of Theology Honours degree with University of South Africa and remain in the circuit. Given her tertiary qualification and the political situation at the time, James did not study as a residential student but underwent her theological training through distance learning.

\section{James's leadership experiences}

James was ordained in 1980 and was appointed Harare District synod secretary. During Rhodesian conferences, she was elected assistant secretary to the secretary of conference (now general secretary). In 1986, the Secretary of Conference, Revd Farai Chirisa, was elected president ${ }^{10}$ (later bishop and now presiding bishop). James was appointed secretary of conference. In February 1988, she was transferred from Kadoma to Mabelreign circuit in Harare to allow her to carry out her duties as secretary of conference close to the connexional (head office). In 1991, the MCZ held its centenary celebrations, and the terms of office of both Bishop Chirisa and James came to a close. Chirisa was replaced by Revd Dr Crispen Mazobere, and James said, ' 1 was asked to assist the new Bishop for a period of one year as Secretary of Conference' (M. James pers. comm., 28 November 2018). After serving for a year, she was replaced by Revd Enos Chibi.

In 1993, James was stationed in Wesley Circuit in Bulawayo. The circuit included the current Aldersgate, Hillside, Northern and Wesley Circuit. In 1994, in his third year in that position, Bishop Mazobere experienced poor health, and Revd Farai Chirisa was re-elected bishop (M. James pers. comm., 28 November 2018). In 1995, James was elected secretary of conference succeeding Revd Enos Chibi. It was from this time that the MCZ resolved to make secretary of conference a full-time post. The administration of the MCZ was by then being carried out by a lay person, and in 1996 Judah Gwatiringa held the position of administrator. He retired at the end of 1996, and James became the first member of the clergy to be a full-time secretary of conference and administrator. Before we analyse how James was appointed acting presiding bishop in 2004, unanticipatedly to serve in that capacity in 2005, it is important firstly to discuss the MCZ succession plan prior to 2004 and the circumstances that led to her appointment one week before she assumed office.

\section{The Methodist Church in Zimbabwe succession plan prior to 2004}

Because of its short terms of office of a minimum of three years and a maximum of five years, the MCZ has a retirement and succession plan for all its leaders (MCZ 2011: 18-19). Presiding bishops in the MCZ are elected by delegates at the annual conference (MCZ 2011: 35). From 1977 until 2004, no evident problems relating to the election process arose. However, in 2004, the MCZ was for the first time faced with a procedural, ecclesiastical and legal crisis. This quandary led the MCZ to change its policy relating to the appointment of presiding bishops from 2005 onwards. Up until then, bishops (presiding bishops) were designated, followed by an election in the ensuing year to confirm the incumbent (MCZ 1997:11). Designation was a process in which a candidate was chosen to act as understudy to the sitting bishop a year before the election. Procedurally, to be elected bishop, a candidate would have been designated at the preceding conference by a ballot and with a clear majority (MCZ 1997:11).

According to this succession plan, the designated bishop was to all effects and purposes a bishop in waiting. This point is clearly made in the DOCOSO (MCZ 1997), which stated:

$[I] \mathrm{n}$ the event of the Bishop of the conference dying, or becoming incapable of acting or unfit to act, then if his successor has been designated, such Bishop Designate shall take office as Bishop forthwith. (p. 11)

The policy (MCZ 1997) further stated:

$[I] \mathrm{n}$ the event of the Bishop Designate dying, or becoming incapable of acting or unfit to act, the Secretary of the Conference shall forthwith call for a meeting of the Standing Committee who shall elect a Bishop Designate. The next conference shall proceed to elect a bishop as its first business. The elected bishop shall take office forthwith. (p. 11)

\section{The 2004 Methodist Church in Zimbabwe leadership crisis}

The MCZ, in accordance with the abovementioned ecclesiastical procedure, designated Revd Dr Charles Mugaviri in 2003 when Revd Cephas Mukandi was in his fourth year as the presiding bishop. The 2004 conference was supposed either to elect another leader or to confirm the designate according to the DOCOSO (MCZ 1997:11). Mugaviri was the youngest minister in the Methodist 
tradition to stand for such a post (Ruwona 2009:68). As the August 2004 conference drew closer, allegations of moral impropriety were made against him (Chimbetete 2004; MCZ 2004:3; Ruwona 2009:67). The matter affected the church socially, in that its standing was compromised. There were ecclesiastic ramifications, with some church members arguing that the senior members of the church were jealous of Mugaviri (Chimbetete 2004). Furthermore, there were financial repercussions for the $\mathrm{MCZ}$, in that a number of members boycotted the church. The MCZ was also faced with a conundrum relating to ecclesiastical procedure, as it had to decide whether to withdraw Mugaviri's candidature as designate presiding bishop or to go ahead and appoint him according to the DOCOSO (MCZ 1997:11).

During the Ministerial Sessions of Conference ${ }^{11}$ of 2004, the eligibility of Mugaviri in the light of the allegations levelled against him was debated. Two motions were moved and seconded: the first was to withdraw Mugaviri's name from the contest, and second that the Ministerial Session allow him to stand as designated by the 2003 conference (Chimbetete 2004; MCZ 2004:3; Ruwona 2009:67). During the ballot in the Ministerial Session, 36 voted for withdrawal, 33 against withdrawal and two were abstentions (MCZ 2004:3).

A quantitative analysis of the above figures and the fact that Mugaviri went ahead to stand for the position of presiding bishop indicate that the Ministerial Sessions of Conference compromised the ecclesiastical voting procedure in two ways. Firstly, Mugaviri's name should have been withdrawn, with 36 votes in favour of this and 33 votes against it. Secondly, the DOCOSO (MCZ 2011) clearly stated that:

$[A] 11$ issues shall be decided by a majority of the members present by voting. In case of votes being equal, the person presiding the meeting shall exercise a second casting vote; or he/she may call for a re-vote by ballot. (p. 11)

The minutes of conference of 2004 contains no evidence of a second vote being taken in the Ministerial session, instead Mugaviri's name was recommended to the representative session $^{12}$ of conference. It is not clear as to why the conference proceeded with Mugaviri's candidature in spite of a vote against doing so. The representative session of conference voted between Mugaviri and Revd Dr Levee Kadenge: there were 71 votes for Mugaviri and 69 for Kadenge (MCZ 2004:42). The matter was put to the vote three times, with the same result being obtained (MCZ 2004:42). A quantitative analysis of these votes also demonstrates that Mugaviri won by a small margin.

11.The Ministerial Session of Conference in the MCZ is the session of the clergy delegates of the conference whose duty is to accept and have oversight of the candidates for ministry; admit probationers; recommend probationers for ordination; deal with the character, discipline, competence and pastoral fidelity of ordination, deal with the character, discipline, competence and pastoral fidelity of to the doctrinal standards (MCZ 2011:14)

12.The Representative Session of the MCZ Conference is a session that comprises both clergy and lay members of the conference. Part of its responsibility is to elect both clergy and lay members of the conference. Part of its responsibility is to elect
the presiding bishop, general secretary, connexional lay president and treasurer the presiding bishd
(MCZ 2011:15).
After the conference, the allegations of adultery persisted, and Mugaviri eventually took the church to the secular courts in a bid to clear his name (Ruwona 2009:69). According to the DOCOSO (MCZ 2011:18: Item 30, 3), the incoming presiding bishop should take office on the first of December. Section 10 of the same policy states that the November Standing Committee should be held towards the end of November and be followed by a public worship service at which the new presiding bishop would be inducted by the outgoing presiding bishop (MCZ 2011:20). According to the then sitting Presiding Bishop, Cephas Mukandi, who was supposed to induct Mugaviri, the incumbent compromised his position as prospective head of the Church by approaching the secular courts (C.Z. Mukandi pers. comm., 11 March 2019). The Standing Committee withdrew Mugaviri's name as presiding bishop designate a week before he was to have assumed duty. Guided by the church policy, the Standing Committee appointed Revd Margaret James, who was not part of the meeting, to be the acting presiding bishop and to assume office within a week (C.Z. Mukandi pers. comm., 11 March 2019). James explained that:

$[T]$ he dilemma faced by the church with regard to its election policy created an opportunity for me to lead the church, although I was not emotionally prepared for such a task at that time. (M. James pers. comm., 28 November 2018)

\section{The leadership experience of Margaret James as the acting presiding bishop}

When James was appointed acting presiding bishop in November 2004, she inherited a church that bore moral scars because its integrity had been challenged; furthermore, from a theological perspective, the church had failed through the secular courts having been approached to solve its ecclesiastical dilemma (1 Cor 3 \& 4). James had proved herself during her years as secretary of conference from 1992 to 1994 in a part-time capacity and from 1996 to 1999 in a full-time capacity (Mujinga 2017:163). The challenge came in 2004, however, when she was appointed acting presiding bishop. There are four possible reasons for the appointment of James in absentia. Firstly, she had the experience of being the secretary of conference, the second-highest position in the MCZ hierarchy. Secondly, it may have been felt that the motherly love of a woman could help heal the scars of the church (C.Z. Mukandi pers. comm., 11 March 2019). Thirdly, James had never competed for the position of the presiding bishop, and that made her a neutral candidate. Fourthly, her neutrality may have been reinforced by the fact that she was the only white minister in a black majority church.

James led the church from December 2004 to August 2005. When such a predicament arises, according to the DOCOSO, the first item of business on the MCZ Conference agenda is the election and induction of the substantive presiding bishop (MCZ 2011:18). The MCZ Conference was once again confronted with a difficult decision rooted in patriarchy. When the time came to elect the substantive presiding bishop, the church chose not to nominate the woman who had 
rescued the church following its involvement in litigation and a power struggle and who had amply demonstrated her leadership ability for the substantive post (Ruwona 2009:69). Instead, a male candidate, Revd Simbarashe Sithole, was appointed with 83 votes against Revd Dr Levee Kadenge, who garnered 63 votes, with two votes having been spoilt (MCZ 2005:19). James, who anticipated being the substantive presiding bishop, was from that moment relegated to the status of former acting presiding bishop and rarely received any acknowledgement during subsequent church gatherings for the contribution she had made (M. James pers. comm., 28 November 2018). An analysis of the way in which James was treated serves as clear evidence that women are extremely competent conflict managers, but that once the conflict has been resolved, their role is all too quickly forgotten.

\section{The rise of Revd Margaret Mawire up the Methodist ecclesiastical ladder}

The interview with Revd Margaret Mawire revealed that she worked in different capacities within the MCZ as a member of the clergy. Her positions included that of youth worker from 1976 to 1980, the chair of the Association of the Women in Christ from 1990 to 1994, Marondera circuit minister and chaplain to Waddiove Institute from 1987 to 1990 and Marondera district chairperson from 1994 to 1999. During her time as district chairperson, she was also a superintendent, as the position was a part-time one until 2004 (C.Z. Mukandi pers. comm., 11 March 2019). Mawire also served as the superintendent of Kwenda Circuit from 1994 to 1997. In 1997, she was transferred to Buhera Circuit, where she completed her last two years as district chairperson, from 1998 to 1999. From Buhera, Mawire was transferred to Trinity Circuit, where she served from 2000 to 2007. This was her first time to minister in the urban circuit.

Mawire trained at UCT, from where she graduated with a Diploma in Theology and a Diploma in Religious Studies in association with the University of Zimbabwe. She also obtained a Bachelor of Arts Honours degree from the University of Zimbabwe. The MCZ seconded her for a scholarship to the British Methodist Church. She was awarded the scholarship and went to the United Kingdom to study for a Master of Arts degree in Applied Theology at Selly Oak Centre of Mission Studies, from 2009 to 2010. Upon her return, she was stationed in Mufakose Circuit. In 2011, she was appointed against all odds to be the first female national director of the Methodist orphanage, the Matthew Rusike Children's Home.

Mawire was appointed from amongst many qualified men as chairperson of the Marondera district and also as the national director. The first appointment posed an enormous challenge because she replaced her husband, Revd Liberty Mawire, who had undergone a disciplinary process (MCZ 1994). This appointment was one of the most difficult experiences in her ministry. Mawire recounted:
I was supposed to be the pastor, administrator and the wife to my husband, and I was supposed to pastor the defaulted minister and nurture him as one of my congregants and yet he was my husband. This alone is contrary to African culture. (M. Mawire pers. comm., 23 April 2019)

Mawire further explained:

$[A] \mathrm{s}$ an administrator, I was supposed to give report to the church where Revd James was the Secretary of Conference and Administrator on whether the former Chairperson who was my husband had repented and was eligible for reinstatement. (M. Mawire pers. comm., 23 April 2019)

This was indeed a difficult assignment. Mawire further stated:

$[M] y$ appointment received a lot of criticism because being a woman and a wife of the defaulted District Chairperson in a patriarchal society, meant I had failed to be a suitable helper and thus could not manage church leadership. (M. Mawire pers. comm., 23 April 2019)

During the interview with Mawire, she described her days as district chairperson as days of sorrow and humiliation, yet felt that God had helped her. Mawire's experience takes us to the narrative of Chishamiso Nyabonda, the first female district bishop to serve following the change in the designation from district chairperson.

\section{The rise of Chishamiso Nyabonda}

Nyabonda worked with Mawire in Trinity as her superintendent in 2008. During her training, Revd James was the coordinator of Theological Education by Extension. In 2009, Nyabonda was transferred from Trinity to Pakame circuit in Gweru district. She remembers the words of her bishop in Gweru, 'You are not urban material. Go to Pakame and pastor the poor rural folk there' (C.E. Nyabonda pers. comm., 15 March 2018). This caused her great distress, 'It was not easy to accept such a denigration from the supposedly spiritual leader' (C.E. Nyabonda pers. comm., 15 March 2018). At Pakame, she served as a circuit minister under the care of the bishop in office at the time. She encountered a certain amount of resistance from the circuit leadership and members in general. During her first Leader's Meeting, ${ }^{13}$ one member said, 'the bishop recommended your stationing here because you are his girlfriend' (C.E. Nyabonda pers. comm., 15 March 2018). She was astonished that laypersons would say such things. In spite of all these difficulties, Nyabonda managed the circuit and she was ordained in 2010. Nyabonda explained further:

I thought ordination was the end of my suffering but was never to be. My suffering continued. The District bishop failed to accept my ordination although I was now the Superintendent of Pakame Circuit, he kept on coming to circuit meetings without my knowledge and making decisions for me. (C.E. Nyabonda pers. comm., 15 March 2018)

13.The Leaders Meeting has authority and oversight over the whole ministry through reports presented by all committees at the church. The Leaders Meeting also manages the property of the church. It initiates actions and coordinates the work done in the church. The meeting is chaired by the superintendent (MCZ 2011:137). 
In spite of facing these many obstacles, Nyabonda was elected to be the post of district synod secretary in 2012. She was by then secretary to the bishop, who was disrespectful towards her in public gatherings or in the executive meetings simply because she was a woman (C.E. Nyabonda pers. comm., 15 March 2018). She explained further, 'The bishop did not accept my appointment as such, he consistently repeated threats of transferring me' (C.E. Nyabonda pers. comm., 15 March 2018). Instead of being transferred out of the district, however, Nyabonda was stationed in the same district, now in urban Shurugwi circuit. Once again, she faced resistance from the congregants. In 2013, a new bishop for Gweru district was appointed, and things became even worse. Nyabonda shared that:

[T]he Bishop did all the district administration with the office secretary with the aim of downplaying my potential. The lay office secretary was tasked with my ministerial duties as Synod Secretary and I did not challenge the bishop although this was difficult for me to understand. (C.E. Nyabonda pers. comm., 15 March 2018)

Nyabonda served in Gweru District for nine years and was the only female minister. Her term of office as synod secretary came to an end in April 2017.

In 2014, the MCZ centralised the elections of district bishops. Each district nominates a candidate any time a position falls vacant in any of the eight MCZ districts (MCZ 2017:33). After the bishops have been elected, they are stationed. Following vacancies in Hwange, Gweru, Harare West and Kadoma, Nyabonda was nominated to represent Gweru District. She was the only female candidate amongst those serving the eight districts. During the $2017 \mathrm{MCZ}$ Annual Conference in Masvingo, male bishops were elected to fill the four vacancies listed above. That year also coincided with the election of the mission director, as the incumbent, Revd Dr Kennedy Gondongwe, had completed his term. The Bishop of Masvingo, Revd Blessmore Chinhara, was appointed as the mission director. The appointment of Chinhara created a fifth vacancy for the position of bishop. The remaining four candidates, in the view of one of the conference delegates, 'were not competent' (C.E. Nyabonda pers. comm., 15 March 2018). The MCZ Conference was torn between choosing from amongst the purportedly incompetent four who had remained, of whom Nyabonda was one, or raise other names from the floor, which was not according to procedure (C.Z. Mukandi pers. comm., 11 March 2019). Nyabonda expressed her dismay when one lay member said, Mutsime hamuchina chinhu tongokwangura [literally: There is no one competent unless we compromise on quality] (C.E. Nyabonda pers. comm., 15 March 2018). The conference eventually agreed to choose from amongst the remaining four candidates, and Nyabonda was elected.

The next question for the Stationing Committee ${ }^{14}$ was which district was going to accept Nyabonda. This question was 14.The Stationing Committee deploys MCZ ministers of the ensuing year on behalf of the conference. also asked by Gweru district, which had nominated her. Fortunately (or unfortunately), Nyabonda was returned to Gweru district, even though this was inconsistent with the appointment tradition (C.E. Nyabonda pers. comm., 15 March 2018). She viewed her stationing in Gweru as a warning to Gweru district, 'Next time, bring competent ministers'. As a way of showing their lack of confidence in Nyabonda's ability, most people in her district address her as 'mother', not 'Bishop' (C.E. Nyabonda pers. comm., 15 March 2018) - this is in spite of the fact that she is unmarried. This Nyabonda interprets as clear evidence that she is not accepted by those whom she leads.

\section{Findings on the obstacles faced by women aspiring to be leaders in the church}

Although feminist ecclesiology is liberative theology that promotes the equality and inclusion of women in church life (Watson 2002:13), this endeavour is not supported in the MCZ. The study showed women to be underrepresented in church leadership positions for reasons including the glass ceiling, male-oriented organisational policies and practices, patriarchal ecclesiastical cultures, stereotyping, gender bias and discrimination against women, and male hegemony.

Firstly, the research concluded that the stories of the women of faith prove that even in the face of patriarchy inherent in their culture and in the Bible, they have the ability to overcome patriarchal obstacles and assume leadership roles within the church. The narratives of Mawire, who succeeded her husband and mentored him following the disciplinary process he was required to undergo, is clear testimony to the fact that women's leadership role unifies the church, and defies the odds in the context of subjugation.

Secondly, the results bear out the view of Nadar (2002:156) that the journey of faith that women undertake and have undertaken has always been one of suffering, caused by oppression by men, and in some cases by women too. More and more people generally see womanhood and manhood as purely a social construct. This situation puts women on the receiving end of discrimination. This point is particularly true with regard to the experience of Nyabonda, who is sometimes called 'mother', in spite of being a bishop and unmarried.

Thirdly, this research supports the view of Phiri (2002:135) that the church is guilty of suppressing women, whom it regards as little more than a nuisance. Once a woman is called to ministry, she is either viewed as having lost her mind or else she is considered to be meddling in things that do not concern her. This point ties in with the fact that the MCZ did not elect the three women whose contributions to the church are explored in this article as its first choice, but as crisis leaders when it felt itself to have no other option.

Fourthly, the research revealed a number of factors that cause women to rise against all odds. These include the charisma of 
the woman herself, her pastoral or administrative ability, her level of education, the general support she may receive from other women, the experience of women in leadership and the voting system of an organisation that consciously creates spaces for women (Eagly \& Karau 2002). Not all of these factors applied to the women whose stories were explored in the study, however. For James, her past leadership experience made her a candidate that the church viewed as worth considering for high office. Mawire was voted into office because she proved to have the potential to carry the mission of the district forward when her husband had failed in the same position. Nyabonda rose against all odds because of the MCZ electoral policy and the general support of the church, and what she termed a 'sympathy vote' (C.E. Nyabonda pers. comm., 15 March 2018).

Fifthly, the three women on whom the research was based experienced unique leadership difficulties. For James, being unmarried, not having children and being the only white in a black-dominated church and first female minister in the MCZ constituted the major obstacles she had to overcome. Yet, the way in which she did so makes her unique in the clerical history of the MCZ. Her situation placed particular obstacles in her path during the course of her ministry, whilst for Nyabonda, being a woman, unmarried and black presented a completely different set of obstacles. In her own words, 'My being female, black and single is a tormenting experience in my pastoral duties because of how African culture views women in leadership' (C.E. Nyabonda pers. comm., 15 March 2018). Mawire had the unique experience of replacing her husband as the district chairperson. Both Mawire and Nyabonda encountered resistance from both women and men because of the patriarchal nature of the MCZ and the cultural life of the congregation, in which women are expected to listen to men. Eagly and Karau (2002:573) expressed this particularly well, 'dominance and competence are agentic behaviours stereotypically expected from men while women are expected to be kind, thoughtful and sensitive'. This cultural life does not accept women who are socially dominant because this quality conflicts with attitudes of femininity niceness.

Sixthly, the research highlighted that women are relationally oriented: they develop a strong social competence, which is often mistaken for moral weakness by both men and women - this is probably why it was insinuated that Nyabonda was involved in a sexual relationship with the bishop.

Seventhly, the research revealed that perceptions about women leaders in the MCZ are very similar to those in the MCSA, which at the time of writing had appointed only one woman, Revd Purity Malinga, to the position of district bishop. She further broke down the patriarchal fence in 2019 by being elected the first female presiding bishop since 1795, when Methodism was introduced in South Africa.
Lastly, the study brought to the fore the fact that men are aware of but struggle to acknowledge the potential of women leaders. This was evident from the congratulatory speech delivered by the Revd Ziphozihle Siwa, the presiding bishop of the MCSA, cited in Shange (2019), on the occasion of the election of Revd Malinga. He said:

$[H]$ aving endured the cross and discrimination of patriarchy for over 200 years, women in MCSA have finally broken through the stained glass ceiling by the election of the first Presiding Bishop who is a woman.

\section{Siwa added that (cited in Shange 2019):}

Revd. Malinga is a tried and tested leader and we rejoice in her election as Presiding Bishop. This decision of the church affirms our belief in the partnership of women and men - and affirms our knowledge and belief in black women in particular - as capable leaders in their own right. (p. 2)

\section{Conclusion}

The leadership experiences of women in general and in the $\mathrm{MCZ}$ in particular provide an illustration of the multitude of difficulties that women face. The research conducted shows that the suppression of women is reinforced not only by patriarchal dominance but also by the general sentiment that women are second-class citizens. Women in both the religious and secular world suffer double stigmatisation in relation to leadership positions. The first is internal, with women undermining other women, and the second is external, with men wanting women to remain subservient to them and in secondary roles. It is possible that because the MCZ drew its ecclesiastical experiences from the MCSA, there is hope in this regard, as it has been demonstrated within the MCSA that women are just as capable as men of leading. It is hoped that the MCZ will follow the example set by her sister conference. The three women whose stories are told in this study differed in terms of training, marital status, background and factors leading to their achievement of leadership positions, and yet the common theme running through their narratives is their capacity, in spite of the prevalence of patriarchy and male domination, nevertheless to rise against all the odds to leadership positions in the MCZ. Their narrative provides proof that to be a woman and a leader in the MCZ is indeed to succeed against all odds.

\section{Acknowledgements}

The author thanks Revd Dr Jimmy Dube for giving access to the Methodist Archives. He also thanks Revd Margareth James, Revd Margareth Mawire and Bishop Chishamiso Nyabonda for sharing their leadership experiences in the Methodist Church in Zimbabwe.

\section{Competing interests}

The author declares that he has no financial or personal relationships that may have inappropriately influenced him in writing this article. 


\section{Author's contributions}

M.M. is the sole author of this research article.

\section{Ethical considerations}

This article followed all ethical standards for research without direct contact with human or animal subjects.

\section{Funding information}

This research received no specific grant from any funding agency in the public, commercial or not-for-profit sectors.

\section{Data availability statement}

Data sharing is not applicable to this article as no new data were created or analysed in this study.

\section{Disclaimer}

The views and opinions expressed in this article are those of the author and do not necessarily reflect the official policy or position of any affiliated agency of the author.

\section{References}

Banana, C.S., 1991, A century of Methodism in Zimbabwe, Mambo Press, Gweru.

Budworth, M.H. \& Mann, S.L., 2010, Becoming a leader: The challenges of modesty for women, viewed 10 August 2019, from https://yorkspace.library.yorku.ca/xmlui/ handle/10315/6305.

Chimbetete, C., 2004, Bishop accused of adultery, viewed 09 August 2019, from https://www.zimbabwesituation.com/old/sep5a_2004.html.

Eagly, A.H. \& Karau, S.J., 2002, 'Role congruity theory of prejudice toward female leaders', Psychological Review 109(3), 573-598. https://doi.org/10.1037/0033295X.109.3.573

Elmuti, D., Jia, H. \& Davis, H.H., 2009, 'Challenges women face in leadership positions and organisational effectiveness: An introduction', Journal of Leadership Education 8(2), 167-187. https://doi.org/10.12806/V8/I2/RF4

Finch, J., 1984, "'It's great to have someone to talk to": The ethics and politics of interviewing women', in C. Bell \& H. Roberts (eds.), Social researching politics, problems and practice, pp. 70-87, Routledge and Kegan Paul, London.

Gippson, A.N., Pfaff, D.L., Mendelsohn, D.B., Catenacii, L.T. \& Bucke, W.W., 2017 'Women and leadership: Selection, development, leadership style and performance', The Journal of Applied Behavioral Science 1(53), 32-65. https://doi. org/10.1177/0021886316687247

Gondongwe, K., 2011, 'African ministers and the emergence of resistance to colonial domination: The development of indigenous clergy in the Wesleyan Methodis Church in Zimbabwe', PhD thesis, School of Religion and Theology, University of KwaZulu-Natal.

Knödel, N., 1997, 'Reconsidering ecclesiology: Feminist perspectives', PhD thesis, Department of Theology, Durham University.
Kumalo, S., 2016, 'From Constance Oosthuizen to Purity Malinga: The struggle for equality in ordination in the Methodist Church of Southern Africa', Studia Historiae Ecclesiasticae 42(2) 174-190 https://doi.org/10.25159/2412 $4265 / 1413$

Madhiba, S., 2010, 'Methodism and political life in Zimbabwe: An analysis of the Wesleyan Methodist Church in Zimbabwe's impact on politics from 1891-1980', PhD thesis, Department of Church History, University of Pretoria.

Methodist Church in Zimbabwe (MCZ), 1997, Deed of church order and standing orders, Literature Department, Harare.

Methodist Church in Zimbabwe (MCZ), 2004, Minutes of the annual conference, Connexional Bookshop, Harare.

Methodist Church in Zimbabwe (MCZ), 2005, Minutes of the annual conference, Connexional Bookshop, Harare.

Methodist Church in Zimbabwe (MCZ), 2011, Deed of church order and standing orders, Connexional Bookshop, Harare.

Methodist Church in Zimbabwe (MCZ), 2017, Minutes of the annual conference, Connexional Bookshop, Harare.

Methodist Church in Zimbabwe (MCZ), 2018, Handbook, Connexional Bookshop, Harare.

Mujinga, M., 2017, The historical development of Methodism: A north-south paradigm, Connexional Bookshop, Harare.

Mujinga, M., 2019, 'Imagining a church with equal opportunities among the clergy: A theological and cultural dilemma in the Methodist Church in Zimbabwe', paper presented at the University of Zimbabwe, Harare, 01 March.

Nadar, S., 2002, 'Journeying is faith: The stories of two ordained Indian women in the Anglican and full Gospel churches in South Africa', in I.A. Phiri, D.B. Govinden \& S. Nadar, (eds.), Her-stories: Hidden histories of women of faith in Africa, pp. 139-155, Cluster Publications, Pietermaritzburg.

Oddi, L.F. \& Cassidy, V.R., 1990, 'Nursing research in the United States: The protection of human subjects', International Journal of Nursing Studies 27(1), 21-33. https:// doi.org/10.1016/0020-7489(90)90020-J

Patton, M.Q. \& Cochrane, M., 2002, A guide to using qualitative research methodology Médecins Sans Frontières, New York, NY.

Paustian-Underdahl, S.C., Slattery Walker, L. \& Woehr, D., 2014, 'Gender and perceptions of leadership effectiveness: A meta-analysis of contextual moderators', Journal of Applied Psychology 99(6), 1129-1145. http://dx.doi. org/10.1037/a0036751

Phiri, I.A., 2002, “"Called at twenty seven and ordained at seventy three!" The story of victory Nomvete Mbanjwa', in I.A. Phiri, D.B. Govinden \& S. Nadar, (eds.), Herstories: Hidden histories of women of faith in Africa, pp. 119-138, Cluster Publications, Pietermaritzburg.

Phiri, I.A., Govinden, D.B. \& Nadar, S. (eds.), 2002, Her-stories: Hidden histories of women of faith in Africa, Cluster Publications, Pietermaritzburg.

Reiners, B., 2019, What is the glass ceiling \& how do we break it? A guide to understanding the glass ceiling metaphor, viewed 03 March 2020, from https:// builtin.com/diversity-inclusion/glass-ceiling.

Ruwona, E., 2009, 'An investigation into the leadership retirement and succession systems and practices of churches in Zimbabwe: A study of the church of the Province of Central Africa (Anglican dioceses of Harare and Manicaland), Methodist Church in Harare', Church in Harare,

Shange, N., 2019, 'Methodist Church of SA appoints its first female Bishop', Times Live, 17 May, p. 2.

Singh, M. \& Durga Prasad, C., 2007, 'The leadership challenges among women managers: An investigation', Journal of Business and Management, 50-55.

The Merriam Webster Dictionary, 2005, Odds, viewed 24 May 2019, from https:// www.merriam-webster.com/dictionary/odds.

Thorpe, C., 1951, Limpopo to Zambesi: Sixty years of Methodism in Southern Rhodesia, Cargate Press, London.

Watson, N., 2002, Introducing feminist ecclesiology, Bloomsbury, London.

Zvobgo, C., 1991, The Wesleyan Methodist missions in Zimbabwe, Longman, Harare. 